\title{
Response of young Bali bulls given Gliricidia and Cassava leaves in rations as a substitute for grass in Bangka Belitung
}

\author{
Zikril Hidayat ${ }^{1}{ }^{*}$, Nuraini $^{1}$, Rubiyo $^{2}$, and Mariyono ${ }^{3}$ \\ ${ }^{1}$ Bangka Belitung Assessment Institute for Agricultural Technology, Jl. Mentok km.4 Pangkalpinang, \\ 33134, Indonesia \\ ${ }^{2}$ Indonesian Center for Agricultural Technology Assessment and Development, Jl. Tentara Pelajar 10 \\ Bogor, Indonesia 16114 \\ ${ }^{3}$ Beef Cattle Research Station, Jl. Pahlawan, Grati-Pasuruan, East Java, Indonesia
}

\begin{abstract}
Gliricidia (Gamal) is a high protein forage source. Gamal contains $24-25 \%$ crude protein. In Bangka Belitung Islands, Gamal is deliberately cultivated as a climbing pole and shade for pepper plants. Usually, Gamal shoots are trimmed once every three months, the leaves can be used as feed. Apart from Gamal, Cassava leaves are also a nutritious feed ingredient. Cassava leaves contain $23.04 \%$ crude protein, $24.86 \%$ dry matter, and $64.87 \%$ dry matter digestibility. This study aims to determine feed consumption, body weight gain, and feed conversion ratio (FCR) of young Bali bulls into small farmers. This research was conducted in Simpang Perlang Village, Central Bangka Regency from June to October 2016. The sample used was 24 young Bali bulls aged 1-3 years with an average live weight of $186.3 \mathrm{~kg}$, which were grouped into 4 (four) feed treatments and 2 (two) age groups, namely 1-2 years and 2-3 years, where each was given 3 (three) replications. Data was analyzed using a completely randomized design and the DMRT test. The results showed that the feed factor and age factor significantly $(\mathrm{P}<0.05)$ had an effect on feed consumption, body weight gain, and FCR.
\end{abstract}

\section{Introduction}

One of the outputs to be achieved in national agricultural development is an increase in cattle productivity. Most livestock productivity is determined by the quality and quantity of feed consumed. The quality of feed depends on the nutrients contained in the feed. The nutrients in question are crude fiber, protein, and energy [1]. Provision of appropriate and quality animal feed can increase the potential for genetic superiority of cattle so as to increase livestock production according to the target.

Wild grass found in nature is still a mainstay for smallholder farmers. Weeds tend to have low nutritional value. Meanwhile, there are many other feed ingredients that contain high nutrients in the form of by-products of plantation crops and in the form of cultivated

*Corresponding author: zikrilhidayat@pertanian.go.id 
grass. This is due to the lack of knowledge of farmers about feed sources and procedures for feeding cattle. The provision of concentrates such as bran, wheat pollar, soybean meal, and others, is also constrained by high prices.

Gamal or Gliricidia and Cassava leaves are plantation waste that is rich in nutrients, and is not expensive. However, they are rarely used as feed ingredients. Gamal is a source of forage which is high in protein. Gamal contains $24-25 \%$ crude protein [2]. In the Bangka Belitung Islands, Gamal is deliberately cultivated as a climbing pole and shade for pepper plants. Usually Gamal shoots are pruned every three months, the leaves can be used as feed. Gamal is a versatile plant, fast growing, capable of fixing nitrogen. Apart from being a source of food, gamal is also a source of wood, fire, green manure, shade trees, and building poles. Gamal production which is carried out every 3 months produces a production of 32.50 tons/ha/year [3]. The digestibility value of the Gamal leaf is $45 \%$, and the bark of Gamal is $60 \%$ [4].

In addition to Gamal, Cassava leaves are also has a high nutritional content. Cassava leaves contain $23.04 \%$ crude protein, $24.86 \%$ dry matter, and $64.87 \%$ dry matter digestibility [5], and digestible energy is $12.538,92 \mathrm{Kkal}$ [6]. Cassava is a new commodity in Bangka Belitung following the decreasing optimism of farmers towards rubber, pepper and oil palm. It can be seen from the significant increase in Cassava harvested area in 2015 from 1,423 Ha to 2,228 Ha in 2017 [7]. This is also supported by the increasing number of Cassava processing factories. One hectare of Cassava plantation can produce 7-15 tons of Cassava leaf waste [8].

Bali cattle are native beef cattle to Indonesia's genetic resources and are the result of the domestication of Banteng thousands of years ago. Bali cattle are a favorite of beef cattle both at home and abroad. Bali cattle are the most widely kept cattle on small farms because of their good fertility and low mortality [9]. Bali cattle have a survival strategy according to agro-ecological conditions and are thought to have phenotypic elasticity in the form of being able to adapt to body conditions and maintain high reproductive power [10].

This study aims to determine feed consumption, body weight gain, and FCR of Bali cattle through substitution of field grass with Gamal and Cassava leaves at the farmer level in Bangka Belitung Islands Province.

\section{Methods}

This research was carried out in the Nadi Lestari farmer group, Simpang Perlang Village, Lubuk Besar District, Central Bangka Regency from June to October 2016. The research sample used was young Bali bulls aged 1-3 years with an average live weight of $186.3 \mathrm{~kg}$ a much as 24 Heads.

This study used a factorial Completely Randomized Design (CRD) with 2 (two) factors. The first factor is the feed formulation consisting of 4 (four) levels of treatment. The treatments given were the existing ration $(\mathrm{R} 1=$ control/ wild grass) and the formulated ration for fattening (R2, R3, R4 = the formulated ration). The composition of feed for each treatment is shown in Table 1 . The second factor is the age of the livestock, namely 1-2 years old (U1) and 2-3 years old (U2). Each treatment consisted of 3 (three) replications. The treatment was given for 98 days, divided into 2 phases, namely the adaptation phase for 14 days, and the treatment phase for 84 days.

Parameters observed in this study include feed consumption, daily body weight gain, and feed conversion ratio. Feed consumption was observed every day by calculating the difference between the amount of feed given and the rest of the feed. Daily body weight gain was calculated based on the difference between the final body weight of the study minus the initial body weight of the study divided by the length of the day of observation. 
Weighing of cattle body weight was carried out every 28 days.. While feed conversion is calculated by comparing the amount of ration consumed with daily body weight gain.

The data obtained were analyzed by means of variance (ANOVA) and if the treatment had a significant effect on the observed variables, the analysis continued with Duncan's further test. SAS 9.4 software was used for data analysis.

Table 1. Feed composition of each treatment

\begin{tabular}{|c|c|c|c|c|}
\hline \multirow{3}{*}{ Feed ingredients } & \multicolumn{4}{|c|}{ Treatment } \\
\hline & R1 & R2 & R3 & R4 \\
\hline & \multicolumn{4}{|c|}{ (- } \\
\hline Wild grass & 100 & 66,7 & 63,4 & 60,0 \\
\hline Gliricidia & - & - & 3,33 & - \\
\hline Cassava leaves & - & - & - & 6,67 \\
\hline Rice bran & - & 12,66 & 12,66 & 12,66 \\
\hline Cassava waste & - & 9,99 & 9,99 & 9,99 \\
\hline Palm kernel cake & - & 8,33 & 8,33 & 8,33 \\
\hline Soy sauce dregs & - & 1,67 & 1,67 & 1,67 \\
\hline Dolomite & - & 0,33 & 0,33 & 0,33 \\
\hline Salt & - & 0,33 & 0,33 & 0,33 \\
\hline Jumlah & 100 & 100 & 100 & 100 \\
\hline
\end{tabular}

\section{Results and discussion}

\subsection{Feed consumption}

The average consumption of dry matter and protein in young Bali bulls is shown in the Table. 2. Based on the results of analysis of variance showed that there was no significant difference in the treatment of substituting grass with Gamal and Cassava leaves on feed consumption.

Consumption of dry matter obtained from this study did not differ in each feed treatment, ranging from 6.75-7.29 kg/day. Dry material consumption in this study was quite high. The dry material requirement for young bulls with a live weight of $200 \mathrm{~kg}$ was 5.6 $\mathrm{Kg}$, equivalent to $2.8 \%$ of live weight [11]. This is because the lightness of the palatability factor is quite high, as stated [12] that the level of livestock consumption is strongly influenced by palatability and the balance of macro and micro nutrients in the ration. Similar results were also obtained by Sunarso et al. who reported that the dry matter consumption of complete feed iso energy (TDN 60-69\%) and protein (12\%) in Simmental cattle ranged from 6.89 to $8.56 \mathrm{~kg} /$ day [13]. The results of this study are higher than those of Nanda et al. who reported that dry matter consumption in Bali cattle fed palm fronds ranged from 2.93 to $3.48 \mathrm{~kg} /$ day [14].

The availability of protein in beef cattle feed is very important because protein is the main component of body organs, enzymes, hormone transporters and so on [11]. Table 2 shows that there is no significant difference in the substitution of grass with Gamal and Cassava leaves on protein consumption. The highest protein consumption was found in the $\mathrm{R} 2$ feed treatment, which was $543.77 \mathrm{~g} / \mathrm{head} /$ day and the lowest protein consumption was found in the R3 treatment, which was $521.82 \mathrm{~g} /$ head/day. Consumption of dry material and protein showed results that were not significantly different between feed treatments. This is in accordance with the statement of Putra and Puger which stated that feed protein was positively correlated with the consumption of dry matter, organic matter, protein and energy [15]. There was no difference in protein consumption in this study, because the protein levels in each treatment were not much different. The results of the Indonesian 
Center for Animal Research and Development laboratory analysis (2020) show that the protein content of field grass is quite high, ranging from $10-13 \%$. The amount of protein consumed in this study is also in accordance with the opinion [11], that young bulls with a live weight of $200 \mathrm{Kg}$, if consuming $554 \mathrm{~g}$ /day of protein can produce $0.5 \mathrm{~kg}$ /day of weight gain.

Based on the results of analysis of variance showed that the difference in age significantly affected the consumption of dry material and protein in Bali bulls. So that as the age of the livestock increases, the consumption of feed also increases. The amount of feed that can be consumed by an animal has a relationship with the weight and size of its body frame where a large body weight and skeleton are able to consume relatively more feed compared to a smaller body weight and skeleton [16].

\subsection{Body weight gain}

Body weight gain is an indicator to determine the rate of livestock growth and the efficiency of the use of the feed given. The performance of cattle is not only influenced by the breed but also the management of feeding. Good feed quality and sufficient amount of feed will increase livestock productivity [17].

The average daily body weight gain of young Bali bulls with treatments R1, R2, R3 and $\mathrm{R} 4$ is shown in the Table. 2. Based on the results of analysis of variance, it showed that there was a significant effect of substitution of grass with gamal and cassava leaves on daily body weight gain.

Table 2. Average dry matter consumption, protein consumption, body weight gain, and FCR during the study

\begin{tabular}{|c|c|c|c|c|c|c|c|}
\hline \multirow{2}{*}{ Parameters } & \multicolumn{4}{|c|}{ Feed } & \multicolumn{2}{|c|}{ Age } & \multirow[t]{2}{*}{ CV } \\
\hline & R1 & $\mathbf{R 2}$ & R3 & R4 & U1 & U2 & \\
\hline $\begin{array}{l}\text { Dry matter } \\
\text { consumption ( } \mathrm{kg} / \text { day) }\end{array}$ & $7,17^{\mathrm{a}}$ & $7,29^{\mathrm{a}}$ & $6,74^{\mathrm{a}}$ & $7,16^{\mathrm{a}}$ & $5,56^{\mathrm{b}}$ & $8,62^{\mathrm{a}}$ & 14,98 \\
\hline $\begin{array}{l}\text { Protein consumption } \\
\text { (g/day) }\end{array}$ & $531,90^{\mathrm{a}}$ & $543,77^{\mathrm{a}}$ & $521,82^{\mathrm{a}}$ & $541,15^{\mathrm{a}}$ & $420,96^{\mathrm{b}}$ & $648,36^{\mathrm{a}}$ & 15,10 \\
\hline $\begin{array}{l}\text { Body weight gain } \\
\text { (kg/day) }\end{array}$ & $0,36^{\mathrm{c}}$ & $0,52^{\mathrm{b}}$ & $0,62^{\mathrm{a}}$ & $0,68^{\mathrm{a}}$ & $0,49^{b}$ & $0,60^{\mathrm{a}}$ & 10,92 \\
\hline FCR & $19,96^{\mathrm{a}}$ & $13,99^{\mathrm{b}}$ & $10,62^{\mathrm{c}}$ & $10,29^{\mathrm{c}}$ & $15,03^{\mathrm{a}}$ & $12,40^{\mathrm{b}}$ & 12,71 \\
\hline
\end{tabular}

Note: different superscripts on the same line show significant differences $(\mathrm{P}<0,05)$

The highest daily body weight gain was obtained in young Bali bulls which were given R4 treatment and the lowest was in R1 treatment. Daily weight gain of young Bali bulls given R4 treatment was significantly different from that of R1 and R2 treatments but not significantly different from R3 treatment. Treatment R3 was also significantly different from treatment R1 and R2 but not significantly different from treatment R4.

One of the factors that affect daily body gains in beef cattle is the quality of the feed consumed. The high and low quality of feed is largely determined by the nutrient content or chemical composition, as well as the high and low levels of anti-nutritional substances contained in it [18]. The quality of feed includes the content of various nutrients, such as energy, protein, minerals, vitamins and the content of anti-nutritional substances such as tannins, lignin and other secondary compounds [1]. To obtain optimal weight gain of beef cattle, a balanced diet of protein and energy is needed. In growing cattle, feeding with a protein amount of $540 \mathrm{~g} / \mathrm{head} /$ day and a metabolic energy content of $32 \mathrm{MJ} / \mathrm{head} / \mathrm{day}$ resulted in the highest live weight gain, $558 \mathrm{~g} /$ day [19]. Feeds with balanced nutrition can 
be obtained by combining various feed ingredients, especially forages and concentrates [18].

The low daily body gains of Bali cattle in treatment R1 was because in this treatment, bali bulls were only given single forage feed (wild grass) without being given additional feed. Single feeding will only meet energy needs for basic energy and a little for growth [20]. The same opinion was also expressed [21] based on the results of his research that the daily weight gain of young Bali bull fed forage without additional feed was lower by 0.10 $\mathrm{kg}$ /day compared to cattle fed additional feed. Beef cattle that were fed minimal feed and with traditional rearing management resulted in an average increase in body weight of about $0.29 \mathrm{~kg} / \mathrm{head} /$ day [22]. The feed formulation treatment with Gamal and Cassava leaf substitution had higher daily weight gains than R1 treatment.

One of the factors that influence the growth rate of a beef cattle is age [23,24]. Based on the results of analysis of variance showed that the difference in age significantly affected the daily body weight gain of Bali cattle. The results of this study showed that young Bali bulls aged 2-3 years grew faster than young Bali bulls aged 1-2 years. The same result was also obtained [25] that a sharp increase in growth occurred at the age of 3 years. Age factor also affects the portion of bone growth, meat and fat. The distribution of meat, bone and fat components shows differences in the growth patterns of each individual animal. Changes in the proportion of carcass components (meat, bone and fat) are in line with growth patterns in livestock, where bone develops the earliest during growth, meat is the carcass component that grows after bone, while fat is the last growing tissue [26]. Adult body will be reached when the body's cells has maximally produced body protein so that there is an increase in fat deposition [27].

\subsection{Feed conversion ratio}

FCR is the amount of feed consumed to obtain an increase in unit live weight [28]. Feed conversion can be used to determine production efficiency because it is closely related to production costs.

The average feed conversion ratio during the study is shown in Table 2. In the table it can be seen that the highest feed conversion value was obtained by treatment R1 (control) of 19.96, while the lowest was obtained by treatment R4 of 10.29. The highest feed conversion (R1) means that the efficiency of feed use is very uneconomical, because to increase daily weight gain by $1 \mathrm{~kg}$ it takes 19.96 of feed. While the low feed conversion as shown in the R4 treatment, provides a higher or better feed use efficiency than the R1 and $\mathrm{R} 2$ treatments because to increase body weight gain by $1 \mathrm{~kg}$ only $10.29 \mathrm{feed}$ is needed. This is due to lightness due to feed metabolism and absorption in the rumen running optimally, because there is an adequacy and balance of feed nutrients needed by livestock. On the other if the feed conversion value is higher, it means the quality of the nutritional value of the feed is getting worse and the livestock is not efficient in using the ration to increase body weight gain [29].

The results obtained are better than those of [30], Bali cattle FCR with fermented straw substitution and shrimp head flour concentrate, which is 17.60. The feed conversion for good beef cattle is 8.56 to 13.29 . FCR of Bali cattle given treatment rations (R3 and R4) is almost the same as the FCR of Bali cattle fed forage with the addition of tofu waste and bioethanol waste, which is 10.94 [31], and is better than the results of other studies, that Bali cattle FCR 14.5-18.5 [16].

The difference in age significantly affected the feed conversion of young Bali bulls (Table 2). In the table it can be seen that the feed conversion value for cattle aged 2-3 (12.40) years is lower than for cattle aged 1-2 years (15.03). This shows that cattle aged 2-3 years are more efficient in using feed than cattle aged 1-2 years. 


\section{Conclusion}

The feed factor had a significant effect on daily weight gain and feed conversion ratio. Meanwhile, age has a significant effect on weight gain, feed consumption, and feed conversion ratio.

Acknowledgements. Acknowledgments are conveyed to the SMARTD manager of the Indonesian Agency for Agricultural Research and Development, as the sponsor who funded this research. Thanks and appreciation are also conveyed to Dr. Ir. Bahtar Bakrie, M.Sc who guided in writing this paper.

\section{References}

1. B. Haryanto, Wartazoa 22, 4 (2012)

2. M. V. Savitri, H. Sudarwati, Hermanto, JIIP 23, 2 (2015)

3. C.C. Wong, Assessment of gliricidia sepium provenance Retalhuleu for forage production at two cutting heights an interval (Livestock Research Center, Malaysia, 2012)

4. D.R.A. Daning, B. Foekh, Sains Peternak. 16, 1 (2018)

5. E. Marhaeniyanto, Buana Sains 7, 1 (2007)

6. A. Irawan, Liman, A.K. Wijaya, Muhtarudin, J. Riset Inov. Peternak. 3, 2 (2019)

7. BPS-Statistics, Kepulauan Bangka Belitung Province in Figures 2017 (BPS-Statistics of Kepulauan Bangka Belitung, 2018)

8. B. Bakrie, Improvement of nutritive quality of crop by-products using bioprocess technique and their uses for animal, http://www.ias.unu.edu/proceedings/icibs/ibs/info/indonesia/bakrie1.htm. (2001)

9. B. Purwantara, R.R. Noor, G. Andersson, H. Rodriguez-Martinez, Reprod. Dom. Anim. 47, 1 (2012)

10. K. Diwiyanto, Pengemb. Inov. Pertan. 1, 3 (2008)

11. L.C. Kearl, Nutrien Requirements Of Ruminants In Developing Countries [All Graduate Theses and Dissertations], (Utah State University Logan, Utah, USA, 1982)

12. N. M. Puspitasari, I. B. G, Partama, I.G.L.O. Cakra, M. I. Pet. 18, 3 (2015)

13. L. K. Sunarso, A. Nuswantara, Setiadi, Budiyono, IJET 11, 1 (2011)

14. D. D. Nanda, A. Purnomoadi, L. K. Nuswantara, Agromedia 21, 2 (2014)

15. S. Putra, A.W. Puger, Manipulasi Mikroba dalam Fermentasi Rumen Salah Satu Alternatif untuk Meningkatkan Efisiensi Penggunaan Zat-zat Makanan (Fak. Peternakan, Univ.Udayana, Denpasar, 1995)

16. E. L. Aditia, R. Priyanto, M. Baihaqi, B. W. Putra, M. Ismail, J. Ilmu Prod. dan Teknol. Has. Peternak. 1, 3 (2013)

17. L.T. T. Huyen, P. Herold, A. Markemann, A.W. Zarate, Anim. Prod. Sci. 51, 7 (2011)

18. U. Umiyasih, Y.N Anggraeny, Ransum seimbang, strategi pakan pada sapi potong [Petunjuk Teknis] (Puslitbang Peternakan, Bogor, 2007)

19. C.M. Thang, I. Ledin, J. Bertilsson, Livest. Sci 128, 1-3 (2010)

20. M. Zulbardi, M. Kuswandi, C. Martawidjaja, C. Thalib, D.B. Wiyono, Daun Gliricidia sebagai sumber protein pada sapi potong, in Prosiding Seminar Nasional Peternakan dan Veteriner, Puslitbang Peternakan, Bogor, Indonesia (2000)

21. D. K. S. Dwi, M.H. Astuti, L.S. Asi, Bul. Peternak. 40, 2 (2016)

22. D. Yuliani, U. Utina, S. Ratnawati. Sistem integrasi padi ternak untuk mewujudkan kedaulatan pangan. In Prosiding Seminar Nasional Pertanian Lahan Kering "Inovasi Pertanian Lahan Kering untuk Mewujudkan Swasembada Pangan dan Daya Saing 
Produk Pertanian“, 5 November 2015, BBP2TP bekerjasama dengan Universitas Nusa Cendana, Kupang, Indonesia (2016)

23. H. Sonjaya, Dasar Fisiologi Ternak, (IPB Press, Bogor, 2012)

24. M. I. Zajulie, M. Nasich, T. Susilawati, Kuswati, Indonesian J. Anim. Sci 25, 1 (2015)

25. M. Latulumamina, Agrinimal 3, 1 (2013)

26. Kuswati, Kusmartono, T. Susilawati, D. Rosyidi, A. Agus, J. Agr. Vet. Sci. 7, 4 (2014)

27. A. C. Echols, Relationships among lifetime measures of growth and frame size for commercial beef females in a pasture-based production system in the Appalachian region of the United States [Tesis] (Faculty of Animal and Poultry Sciences, Virginia Polytechnic Institute, USA, 2011).

28. T. W. Perry, A.E. Cullison, R.S. Lowrey, Feed and Feeding. 6nd Ed. (Pearson Education, Inc. Upper SaddleRiver, New Jersey, 2005)

29. B. Widianto, H.S. Prayogi, Nuryadi, J. Anim. Sci. 25, 2 (2011)

30. A. Ella, D. Pasambe, A. Nurhayu, Penggemukan Sapi Bali dengan Substitusi Jerami Fermentasi dan Konsentrat Tepung Kepala Udang di Kabupaten Pinrang, Sulawesi Selatan, in Prosiding Seminar Nasional Teknologi Peternakan dan Veteriner, (Puslitbang Peternakan, Bogor, 2017)

31. D. D. K. Sari, M. H. Astuti, L. S. Asi, Bul. Peternak. 40, 2 (2016) 